\title{
Pyruvic Acid Metabolism and Ethanol Formation in Erwinia amylovora
}

\author{
By A. HAQ* AND E. A. DAWES \\ Department of Biochemistry, University of Hull, Kingston upon Hull, HU6 ${ }_{7} R X$
}

(Accepted for publication 24 July 197I)

\begin{abstract}
SUMMARY
Erwinia amylovora is the first member of the Enterobacteriaceae found to possess a thiamine pyrophosphate-dependent pyruvate decarboxylase yielding acetaldehyde and $\mathrm{CO}_{2}$. In conjunction with an NAD-dependent ethanol dehydrogenase this represents the route of ethanol formation and explains the high ethanol yields previously reported. The organism also possesses an $\alpha$-acetolactate decarboxylase and is thus able to produce acetoin by both the recognized microbial pathways. Fermentation balances for pyruvate with bacterial suspensions and extracts at $\mathrm{pH} 6 \cdot 0$ are recorded. NADH oxidase and lactate dehydrogenase are present but NADHNADP transhydrogenase, coenzyme A-dependent acetaldehyde dehydrogenase, formate dehydrogenase or formate hydrogenlyase could not be detected. The findings are discussed in relation to the classification of Erwinia and the comparative biochemistry of the Enterobacteriaceae.
\end{abstract}

\section{INTRODUCTION}

Enzymic and isotopic studies have established the operation of the Embden-Meyerhof glycolytic and hexose monophosphate oxidative pathways of glucose metabolism in the plant pathogen Erwinia amylovora (Katznelson, I958; Sutton \& Starr, I960); the EntnerDoudoroff pathway is absent (De Ley, I962). Sutton \& Starr (1959) reported a yield of I. 55 moles of ethanol per mole of glucose fermented, which suggested to us the possibility of a yeast-type pyruvate decarboxylase yielding $\mathrm{CO}_{2}$ and acetaldehyde, which could then be reduced to ethanol by ethanol dehydrogenase. Pyruvate decarboxylase has, however, only a very limited distribution in bacteria and has not previously been found in the Enterobacteriaceae, in which family the genus Erwinia is placed. As the characteristic fermentation patterns of the Enterobacteriaceae reflect the pathways for the further metabolism of pyruvate, we have investigated the metabolism of this compound by $E$. amylovora in relation to the mechanism of ethanol formation and the comparative biochemistry of the Enterobacteriaceae.

\section{METHODS}

Organism. The organism used throughout this work was Erwinia amylovora EA I $37 \mathrm{~S}$ which was kindly supplied by Professor M. P. Starr (University of California, Davis, U.S.A.) who had taken the strain from a parent culture EA I37, originally isolated from fire-blight of apple by Ark (1937). Both EA I37 and EA I37s were plant pathogenic when tested by Ark during the studies of Sutton \& Starr ( I959) and were typical of E. amylovora in their biochemical reactions. For comparative studies of formate metabolism we have also used

\footnotetext{
* Present address: Institute of Psychiatry, University of London, The Maudsley Hospital, De Crespigny
} Park, Denmark Hill, London S.E. 5. 
strains 100, 675 and 830 from the National Collection of Plant Pathogenic Bacteria, Harpenden, Herts.

Media and growth of the organism. Erwinia amylovora was maintained on Oxoid nutrient agar of composition (g./1. distilled water): Lab Lemco beef extract, I 0 ; yeast extract, $2 \cdot 0$; peptone, $5.0 ; \mathrm{NaCl}, 5 \cdot 0 ;$ agar, $15 \cdot 0 ; \mathrm{pH}_{7} \cdot 4$. The cultures were grown aerobically on nutrient agar slants at $30^{\circ}$ for 36 to $48 \mathrm{~h}$. and then stored at $4^{\circ}$. Subcultures were made at monthly intervals.

Liquid cultures were grown, as appropriate, in three different media. (a) Chemically defined medium contained (g./l. distilled water): $\mathrm{NH}_{4} \mathrm{Cl}, \mathrm{I} \cdot 0 ; \mathrm{KH}_{2} \mathrm{PO}_{4}, 4 \cdot 0 ; \mathrm{K}_{2} \mathrm{HPO}_{4}, 4 \cdot 0$; $\mathrm{MgSO}_{4} \cdot 7 \mathrm{H}_{2} \mathrm{O}, 0.2$; glucose, 4.0 ; sodium malate, 4.0 ; nicotinic acid, $2 \mathrm{mg}$. and $10 \mathrm{ml}$. of trace elements solution (see below). (b) Complex medium was medium $\mathrm{A}$ to which was added (g./1.): casamino acids (Difco), 2; yeast extract (Difco), I. (c) Neopeptone medium contained (g./1.): $\mathrm{NH}_{4} \mathrm{Cl}, \mathrm{I} \cdot 0 ; \mathrm{KH}_{2} \mathrm{PO}_{4}, 4 \cdot 0 ; \mathrm{K}_{2} \mathrm{HPO}_{4}, 4 \cdot 0 ; \mathrm{MgSO}_{4} \cdot 7 \mathrm{H}_{2} \mathrm{O}, 0 \cdot 2 ;$ glucose, 4.0 ; neopeptone (Difco), 4.0 ; nicotinic acid, $2 \mathrm{mg}$. and $\mathrm{IO} \mathrm{ml}$. of trace elements solution. The $\mathrm{pH}$ of media was adjusted to $6 \cdot 8$.

The trace elements solution contained (mg./l.): $\mathrm{H}_{3} \mathrm{BO}_{3}, 0.5 ; \mathrm{CaCO}_{3}, \mathrm{Io} ; \mathrm{CuSO}_{4} \cdot 5 \mathrm{H}_{2} \mathrm{O}, \mathrm{I}$; $\mathrm{FeSO}_{4}\left(\mathrm{NH}_{4}\right)_{2} \mathrm{SO}_{4} .6 \mathrm{H}_{2} \mathrm{O}$, Io; KI, O.I; $\mathrm{MnSO}_{4} .4 \mathrm{H}_{2} \mathrm{O}$, I; $\mathrm{MoO}_{3}, \mathrm{I} ; \mathrm{ZnSO}_{4} .7 \mathrm{H}_{2} \mathrm{O}, 5$ (Starr, 1946). It was sterilized by Seitz filtration.

Glucose was autoclaved separately at $10 \mathrm{lb}$./in. ${ }^{2}$ for $15 \mathrm{~min}$. and, with the trace elements solution, added aseptically to the media.

The organism grew optimally at 28 to $30^{\circ}$; very little growth occurred above $34^{\circ}$. Growth was poor under anaerobic conditions in media $\mathrm{B}$ and $\mathrm{C}$ and absent in medium $\mathrm{A}$.

Cultures (I2.5 ml.) for use as inocula were grown at 28 to $30^{\circ}$ in $50 \mathrm{ml}$. Erlenmeyer flasks in a Gallenkamp shaking bath (I 20 oscillations/min., stroke $3.8 \mathrm{~cm}$.) or on a New Brunswick two-tier gyrotary shaker for 20 to $22 \mathrm{~h}$. Larger cultures ( $\mathrm{I}$ to $2 \mathrm{l}$.) were grown in 41 . widenecked conical flasks on the gyrotary shaker at $30^{\circ}$ for $\mathrm{I} 2 \mathrm{~h}$. In each experiment an inoculum $(0 . \mathrm{I}$ to $0.2 \%, \mathrm{v} / \mathrm{v})$ of bacteria $(0.8 \mathrm{to} \mathrm{I} \cdot 0 \mathrm{mg}$. dry $\mathrm{wt} / \mathrm{ml}$.) from the appropriate medium was used. A lag phase of about I to $2 \mathrm{~h}$. in aerobic and 4 to $5 \mathrm{~h}$. in anaerobic culture was usually observed.

Preparation of washed bacterial suspensions. Bacteria were harvested at the onset of the stationary phase, washed twice with $0.076 \mathrm{M}$-K-phosphate buffer, $\mathrm{pH} 7 \cdot \mathrm{I}$, and suspended in an appropriate buffer solution. The organisms were either sedimented for $15 \mathrm{~min}$. at $5000 \mathrm{~g}$ or for $5 \mathrm{~min}$. at $23,000 \mathrm{~g}$ on an M.S.E. Major or Servall SS-I centrifuge at room temperature (about $20^{\circ}$ ). Suspensions were used normally within an hour of preparation. Centrifuged bacterial pellets could be stored overnight at $4^{\circ}$ without appreciable loss of activity.

Bacterial extracts. These were prepared by disrupting $10 \mathrm{ml}$. portions of bacterial suspensions (about 0.2 to $0.3 \mathrm{~g}$. wet $\mathrm{wt} / \mathrm{ml}$.) with an M.S.E. ultrasonic disintegrator operated at $\mathrm{I} 8$ to $20 \mathrm{Kc}$./sec. with a current output of $\mathrm{I} \cdot 3$ to $\mathrm{I} \cdot 5 \mathrm{~A}$. Each sample was treated for three periods of $50 \mathrm{sec}$. each separated by cooling intervals of $5 \mathrm{~min}$. The sample vials were surrounded by crushed ice and the temperature of the contents never allowed to rise above $15^{\circ}$. The resulting preparations were centrifuged for $20 \mathrm{~min}$. at $17,000 \mathrm{~g}$ and $0^{\circ}$ in the Superspeed unit of an M.S.E. Major centrifuge. The pale pinkish brown supernatant was transferred to pre-cooled Universal bottles and held at $4^{\circ}$ or at $-14^{\circ}$ according to requirements. Extracts held at $4^{\circ}$ were used within $\mathrm{I}$ to $2 \mathrm{~h}$. of preparation and those stored at $-14^{\circ}$ were used within $72 \mathrm{~h}$. without significant loss of enzymic activity. Sonication for I to $2.5 \mathrm{~min}$. gave extracts with maximum specific activities for pyruvate decarboxylase. For acetaldehyde dehydrogenase assays extracts were also prepared by grinding with powdered glass (Strecker, Wood \& Krampitz, I950), by the Hughes's (I95I) press and by the method of Lamanna \& Mallette (1954). 
Fermentation balances. The fermentations were carried out in replicate Warburg flasks each containing I. $8 \mathrm{ml}$. $0.1 \mathrm{M}-\mathrm{K}$-phosphate buffer, $\mathrm{pH} 6 \cdot 0 ; 0.5 \mathrm{ml}$. bacterial suspension $(38 \cdot 4 \mathrm{mg}$. dry $\mathrm{wt} / \mathrm{ml}$. of same buffer) or extract (34. I mg. protein $/ \mathrm{ml}$. buffer); $0.5 \mathrm{ml}$. $0 . \mathrm{I}$ M-pyruvate side arm I) and $0.2 \mathrm{ml} .5 \mathrm{~N}-\mathrm{H}_{2} \mathrm{SO}_{4}$ (side arm 2). Chemical and biological controls were run in parallel with acid tipped at zero and final time. The atmosphere was $\mathrm{N}_{2}$ and the temperature $30^{\circ}$. The reaction was started after $20 \mathrm{~min}$. incubation by tipping pyruvate into the main compartment. Acid was tipped at the conclusion. Usually nine flasks were set up and the contents pooled for analysis. After taking the final reading flasks were cooled in ice before detachment from manometers. The contents were transferred quantitatively to pre-cooled centrifuge tubes, the bacteria sedimented and the supernatant clarified and neutralized with zinc hydroxide by the method of Neish (1952) before analysis. Residual pyruvate was determined.

Enzyme assays. The assay methods for pyruvate decarboxylase, NADH oxidase, alcohol dehydrogenase, lactate dehydrogenase and $\alpha$-acetolactate decarboxylase are given in the legends to the appropriate Figures and Tables.

Acetaldehyde dehydrogenase. The method of Dawes \& Foster (1956) was applied to crude, ultracentrifuged and ammonium sulphate-fractionated extracts with and without supplements of coenzyme $\mathrm{A}, \mathrm{MgSO}_{4}$ and glutathione. Cells were grown on media $\mathrm{A}, \mathrm{B}$ and $\mathrm{C}$ and extracts were prepared in a variety of ways. Assays were run over a range of $\mathrm{pH}$ values in different buffers and at different temperatures $\left(20\right.$ to $\left.30^{\circ}\right)$.

Pyruvate-formate lyase (thioclastic enzyme). The enzyme was assayed by the formatepyruvate exchange reaction using $\left[{ }^{14} \mathrm{C}\right]$-formate (Strecker, Wood \& Krampitz, 1950). Each Warburg flask contained: I ml. O.I M-K-phosphate buffer, pH 6.8; 0.25 ml. 0.192 M-[14C]formate $\left(2 \times 10^{6}\right.$ counts $/ \mathrm{min} . / \mathrm{ml}$.) in side arm I; bacterial extract $(15.7 \mathrm{mg}$. protein $/ \mathrm{ml}$.); $0.2 \mathrm{ml} .3 \mathrm{~N}-\mathrm{H}_{2} \mathrm{SO}_{4}$ in side arm 2. Where appropriate, $0.2 \mathrm{ml} .0 .2 \mathrm{M}$-pyruvate (in side arm I with formate) and $0.5 \mathrm{ml}$. of boiled aqueous extract of yeast ( $15 \mathrm{mg} . / \mathrm{ml}$.) or of Erwinia amylovora (from $0.2 \mathrm{~g}$. cell wet $\mathrm{wt} / \mathrm{ml}$.) were added. The final volume in each fiask was made to $3 \mathrm{ml}$. with distilled water and the reactions were run at $30^{\circ}$ under $\mathrm{N}_{2}$. Chemical controls (no enzyme) were set up with each reaction mixture. Acid was tipped after $15 \mathrm{~min}$. to stop the reaction and the contents of the flasks were centrifuged at $17,500 \mathrm{~g}$ for $15 \mathrm{~min}$. Supernatants were treated with an equal volume of 2,4 -dinitrophenylhydrazine $(0.1 \%(\mathrm{w} / \mathrm{v})$ in $2 \mathrm{~N}-\mathrm{HCl}$ ) and incubated at $37^{\circ}$ for $30 \mathrm{~min}$. Pyruvate 2,4-dinitrophenylhydrazone was extracted into ethyl acetate and then into $10 \%(\mathrm{w} / \mathrm{v}) \mathrm{Na}_{2} \mathrm{CO}_{3}$. After acidification with $\mathrm{Io} \mathrm{N}_{-} \mathrm{H}_{2} \mathrm{SO}_{4}$ the hydrazone was extracted again into ethyl acetate, the organic layer separated and washed with water. After centrifuging to remove traces of water, the solution was concentrated and 0.05 to $0 . \mathrm{I} \mathrm{ml}$. portions used for ascending paper chromatography in butan-I-ol saturated with $0.2 \%$ ammonia. The two isomeric pyruvate 2,4 -dinitrophenylhydrazones were cut out from the paper, eluted with $2 \mathrm{ml}$. distilled water, and portions $(0.2 \mathrm{ml}$.) placed on nickel planchets $\left(2.5 \mathrm{~cm}\right.$. diam., area $\left.4.9 \mathrm{~cm} .{ }^{2}\right)$, dried and counted in a Nuclear Chicago gas flow counter for $100 \mathrm{~min}$.

Formate dehydrogenase and formate hydrogenlyase were assayed by the methods of Bauchop \& Dawes (1968). Methylene blue, benzyl viologen and cytochrome $c$ were all tested as electron acceptors in the formate dehydrogenase assays.

Lactate dehydrogenase was assayed by the method of Wieland (1963).

Pyruvate apo-decarboxylase. The preparation of pyruvate apo-decarboxylase was attempted by the methods of Holzer, Söling, Goedde \& Holzer (I963) for yeast, and of Morey \& Juni (1968).

Buffers. All buffers were prepared according to Gomori (1955) unless otherwise stated; pH was determined with an E.I.L. 23 A Direct Reading pH meter. 
Chemical determinations. Pyruvate was determined by the toluene extraction method of Friedemann \& Haugen (I943), acetaldehyde by the procedure of Johnson \& Scholes (1954), ethanol by the enzymic method of Bonnichsen (I963) and lactate by the method of Hullin \& Noble (I953). Acetoin, diacetyl and butane 2,3-diol were determined by the methods described by Neish (1952). Organic acids were extracted from fermentation liquors with ether, separated by partition chromatography on silicic acid columns according to Neish (1952) and titrated with $0.01 \mathrm{~N}-\mathrm{NaOH}$ with $0.5 \%(\mathrm{w} / \mathrm{v})$ phenol red as indicator. $\mathrm{CO}_{2}$-free air was bubbled through the solutions during titration. Protein was determined by the biuret method of Stickland (I95I) and $\mathrm{CO}_{2}$ evolution measured by conventional Warburg manometry at $30^{\circ}$ under $\mathrm{N}_{2}$ (Umbreit, Burris \& Stauffer, 1964).

Chemicals and enzymes. Chemicals of analytical reagent grade were used whenever possible. Pyruvic acid, acetaldehyde and formic acid were always redistilled before use and $p$-hydroxydiphenyl was recrystallized from ethanol. 2,4-Dinitrophenylhydrazones of acetaldehyde and pyruvic acid were prepared and recrystallized twice from ethanol. Sodium pyruvate and sodium formate were freshly prepared in each experiment from the redistilled acids. Alcohol dehydrogenase, NAD, NADH, NADP, NADPH (sodium salts) were obtained from C. F. Boehringer und Soehne, Mannheim, Germany. Acetyl CoA, coenzyme A, pyrithiamine (neo) hydrobromide and albumin (bovine fraction $V$ ) were obtained from Sigma Chemical Co., St Louis, Missouri. $\alpha$-Acetolactic acid acetate ethyl ester was from K \& K Laboratories Inc., New York. Casamino acids, yeast extract and neopeptone were from Difco Laboratories, Detroit, Michigan; cocarboxylase and glutathione were from British Drug Houses, Poole, Dorset; 2,4-dinitrophenylhydrazine and powdered glass were from Hopkin \& Williams Ltd., Essex, and silicic acid (I00-mesh) from Mallinckrodt Chemical Works, St Louis, Missouri. Sodium $\left[{ }^{14} \mathrm{C}\right]-$ formate was obtained from the Radiochemical Centre, Amersham, Buckinghamshire.

$\alpha$-Acetolactic acid was prepared by the hydrolysis of $\alpha$-acetolactic acid acetate ethyl ester with $\mathrm{NaOH}$, as described by Krampitz (1948). The mixture of ethanol and the sodium salts of $\alpha$-acetolactic and acetic acids resulting from the hydrolysis was used as such in the experiments to assay $\alpha$-acetolactate decarboxylase. The yield of $\mathrm{CO}_{2}$ from $\alpha$-acetolactate in the mixture was $84.3 \%$ of theoretical.

\section{RESULTS}

Fermentation balances for anaerobic pyruvate dissimilation. Table I records the fermentation balances for pyruvate with whole organisms and with extracts in phosphate buffer at $\mathrm{pH}$ 6.0. Lactate, acetate, acetaldehyde and $\mathrm{CO}_{2}$ were the major products with intact organisms with acetoin, diacetyl and formate as minor products. In contrast, the corresponding fermentation by bacterial extracts resulted in a substantial increase in acetoin and $\mathrm{CO}_{2}$, and a decrease in lactate and, to a lesser extent, acetate. Succinate was not determined in these experiments. With the exception of acetaldehyde, the products were those associated with fermentations of the Enterobacteriaceae, and the presence of the relevant enzymes was therefore investigated.

\section{Enzyme assays}

Detection and characterization of pyruvate decarboxylase. Washed suspensions of Erwinia amylovora evolved a gas, which was completely absorbed by $\mathrm{KOH}$, from pyruvate in citratephosphate buffer at $\mathrm{pH} 6 \cdot 0$ under an atmosphere of $\mathrm{N}_{2}$. As no other gas was released, this was assumed to be $\mathrm{CO}_{2}$. The stoichiometry over the range of 2 to $\mathrm{Io} \mu$ moles of pyruvate was $0.64 \mathrm{~mole}^{\mathrm{CO}} /$ mole pyruvate, confirming the occurrence of competing reactions as indicated 


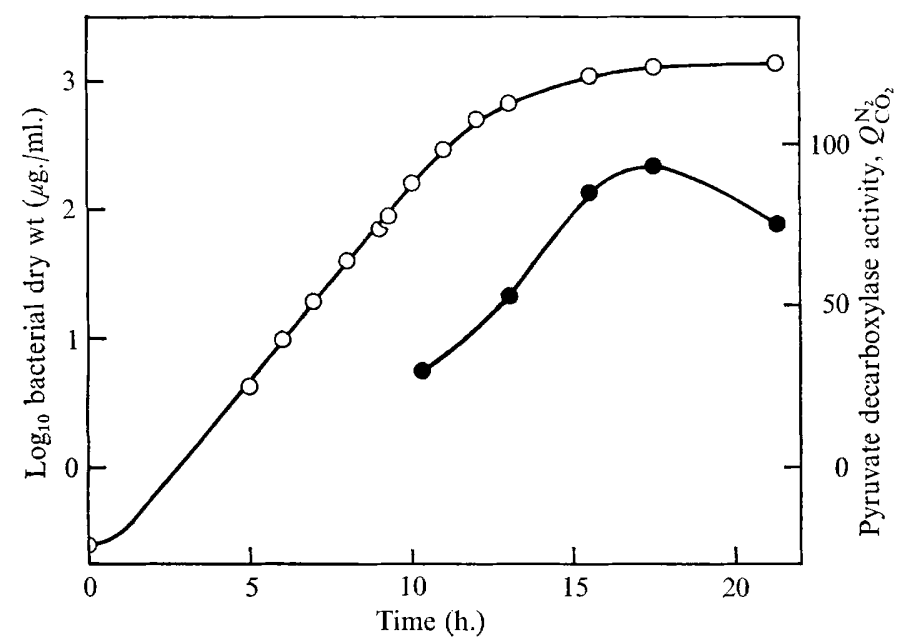

Fig. I. Pyruvate decarboxylase activity of whole organisms in relation to their growth cycle in complex medium. Growth, $O$; pyruvate decarboxylase activity, $Q_{\mathrm{c}}^{\mathrm{N}_{2}}$,

Table I. Anaerobic dissimilation of pyruvate by bacterial suspensions and extracts of Erwinia amylovora

\begin{tabular}{|c|c|c|c|c|}
\hline \multirow[b]{2}{*}{ Products } & \multicolumn{2}{|c|}{ Bacterial suspension } & \multicolumn{2}{|c|}{ Bacterial extract } \\
\hline & $\begin{array}{l}\text { Mole/mole } \\
\text { pyruvate }\end{array}$ & $\begin{array}{l}\text { Carbon } \\
\text { recovery }\end{array}$ & $\begin{array}{c}\text { Mole/mole } \\
\text { pyruvate }\end{array}$ & $\begin{array}{l}\text { Carbon } \\
\text { recovery }\end{array}$ \\
\hline Carbon dioxide & 0.633 & 0.633 & 0.852 & 0.852 \\
\hline Acetaldehyde & 0.207 & $0.4 \mathrm{I} 4$ & 0.172 & 0.344 \\
\hline Acetoin & 0.0776 & $0 \cdot 310$ & 0.230 & 0.923 \\
\hline Butane 2,3-diol & - & - & 0.036 & $0 \cdot I 44$ \\
\hline Diacetyl & 0.013 & 0.052 & 0.018 & 0.072 \\
\hline Acetic acid & 0.224 & 0.448 & 0.132 & 0.264 \\
\hline Lactic acid & 0.272 & 0.816 & 0.064 & $0 \cdot 192$ \\
\hline Formic acid & 0.044 & 0.044 & 0.012 & 0.012 \\
\hline \multirow[t]{2}{*}{ Ethanol } & - & 一 & $0.0 \mathrm{II}$ & 0.022 \\
\hline & & $2 \cdot 717$ & & $2 \cdot 825$ \\
\hline Carbon recovery, $(\%)$ & & $90 \cdot 3$ & & $94 \cdot 2$ \\
\hline Oxidation-reduction index & & 0.95 & & 0.96 \\
\hline
\end{tabular}

by the fermentation balance. If higher initial concentrations of pyruvate were used, e.g. I $3.3 \mathrm{~mm}$ instead of $3.3 \mathrm{~mm}$, and the reaction halted before completion, a yield of $0.8 \mathrm{I}$ mole $\mathrm{CO}_{2} /$ mole pyruvate was observed. The formation of acetaldehyde was suggested by its characteristic odour and established by the isolation of a 2,4-dinitrophenylhydrazone which gave a spectrum $\left(E_{\max } 356 \mathrm{~nm}\right.$.) and melting-point ( $\mathrm{I}_{4} 8$ to $\left.\mathrm{I} 5 \mathrm{I}^{\circ}\right)$ characteristic of acetaldehyde. The melting-point of acetaldehyde 2,4-dinitrophenylhydrazone is known to cover a range of I 48 to $168.5^{\circ}$ (Allen, 1930; Strain, I935; Ross, I953; Kramer \& van Duin, I954; Timmons, 1957), a fact usually attributed to the differing proportions of two isomers; an authentic specimen prepared from acetaldehyde under our conditions gave a melting point of 158 to I $59^{\circ}$. The presence of pyruvate decarboxylase was therefore inferred.

Assays with bacteria harvested throughout the growth cycle indicated maximum decarboxylase activity at the onset of the stationary phase (Fig. I) and the optimum $\mathrm{pH}$ was 
6.o. Comparison of whole and disintegrated bacteria revealed a partial permeability barrier to pyruvate. For example, under comparable conditions reaction with $50 \mu$ moles pyruvate was complete in $\mathrm{I}$ h. with disintegrated cells but took $3 \mathrm{~h}$. with whole cells; the $\mathrm{CO}_{2}$ yields were 85 and $63 \%$ respectively.

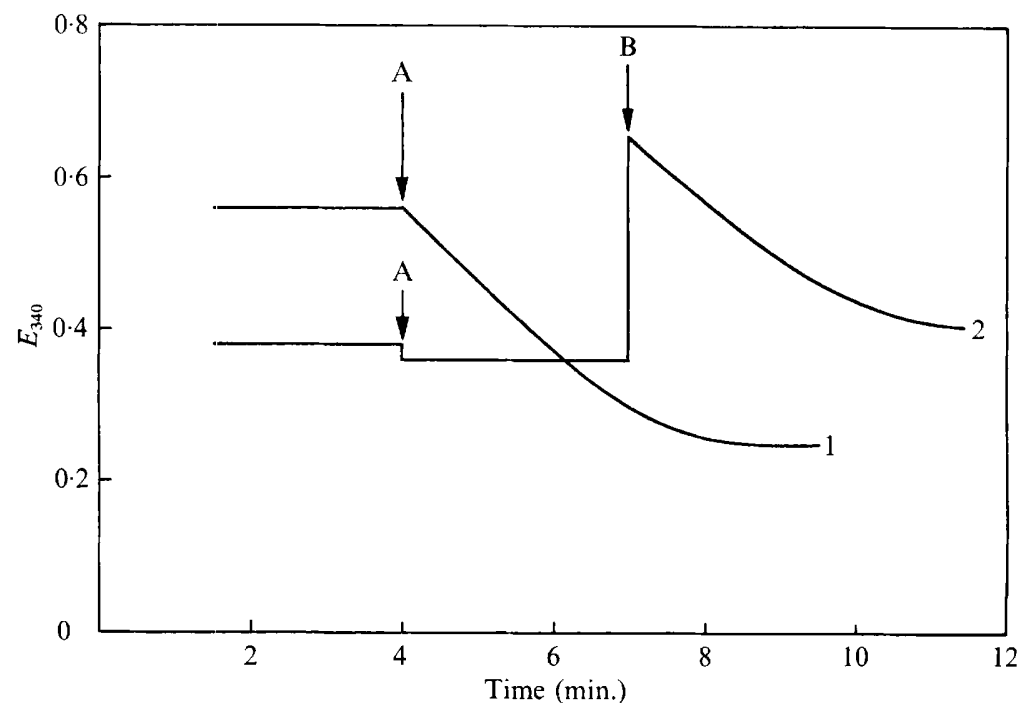

Fig. 2. NADH oxidase. Cuvettes contained: $2.4 \mathrm{ml}$. $0.06 \mathrm{M}-\mathrm{K}-\mathrm{phosphate,} \mathrm{pH} 7.0 ; 0.2 \mathrm{ml}$. I mM$\mathrm{NADH}$ or NADPH; $0^{-1} \mathrm{ml}$. bacterial extract (1 $3 \mathrm{mg}$. protein $/ \mathrm{ml}$. buffer) and water to $3 \mathrm{ml}$. Assay I, $\mathrm{NADH} ; 2$, NADPH. Reaction was initiated by addition of extract at A. $0.2 \mathrm{ml}$. I mM-NADH was added to assay 2 at $\mathrm{B}$. Temperature $22^{\circ}$.

\section{Table 2. Effect of inhibitors on $\mathrm{CO}_{2}$-release from pyruvate}

Each Warburg flask contained: $1.5 \mathrm{ml}$. $0 . \mathrm{I}$ M-citrate-phosphate buffer, $\mathrm{pH} 6.0 ; 0.5 \mathrm{ml}$. bacterial extract in the same buffer $(5 . \mathrm{I} \mathrm{mg}$. protein $/ \mathrm{ml}$.); $0.5 \mathrm{ml}$. $0.05 \mathrm{M}$-sodium-pyruvate (in the side arm)

\begin{tabular}{|c|c|c|c|}
\hline Inhibitor & $\begin{array}{c}\text { Concentration } \\
(\mathrm{mM})\end{array}$ & $Q_{\mathrm{CO}_{2}}^{\mathrm{N}_{2}}$ & $\begin{array}{c}\text { Inhibition } \\
(\%)\end{array}$ \\
\hline None & & II 4 & 0.0 \\
\hline \multirow[t]{3}{*}{$\mathrm{AgNO}_{3}$} & $0 . I$ & 92 & $19 \cdot 2$ \\
\hline & 0.2 & 76 & $33 \cdot 2$ \\
\hline & $2 \cdot 0$ & 0.0 & $100 \cdot 0$ \\
\hline \multirow[t]{3}{*}{$\mathrm{CuSO}_{4}$} & 0.1 & 92 & $19 \cdot 2$ \\
\hline & $0 \cdot 2$ & $8 I$ & $28 \cdot 9$ \\
\hline & $2 \cdot 0$ & 0.0 & $100 \cdot 0$ \\
\hline \multirow[t]{3}{*}{ Pyrithiamine (neo) } & $0 \cdot I$ & 121 & 0.0 \\
\hline & $0 \cdot 2$ & 120 & 0.0 \\
\hline & $2 \cdot 0$ & 125 & 0.0 \\
\hline
\end{tabular}

The activity of many bacterial extracts was stimulated by the addition of $0.13 \mathrm{~mm}$ thiamine pyrophosphate plus $6.4 \mathrm{~mm}-\mathrm{Mg}^{2+}$. Respective rates $\left(\mu 1 . \mathrm{CO}_{2} / \mathrm{mg}\right.$. protein $/ \mathrm{h}$.) in two such experiments were $(a) 200$ and 232 , and $(b) 82$ and 133 . The enzyme proved extremely difficult to resolve, however, and methods satisfactory for other micro-organisms failed to produce complete resolution. While some variation occurred in different experiments, a fairly typical case gave rates $\left(\mu 1 . \mathrm{CO}_{2} / \mathrm{mg}\right.$. protein $/ \mathrm{h}$.) of 88 for crude, 40 for 'resolved' and 
73 for 'resolved' plus co-factors. $\mathrm{AgNO}_{3}$ and $\mathrm{CuSO}_{4}$ inhibited decarboxylase activity but pyrithiamine was without effect (Table 2).

NADH oxidase. Extracts of Erwinia contained an active NADH oxidase (Fig. 2) which had an optimum $\mathrm{pH}$ of $7 \cdot 2$ but retained more than $60 \%$ of its activity over the $\mathrm{pH}$ range 6.4 to $8 \cdot 0$. The bulk of the enzyme could be precipitated by 20 to $40 \%$ saturation with $\left(\mathrm{NH}_{4}\right)_{2} \mathrm{SO}_{4}$ but was completely sedimented by centrifuging at $105,000 \mathrm{~g}$ for $90 \mathrm{~min}$. It did not oxidize NADPH. As the enzyme interfered with spectrophotometric assays of NAD-linked enzymes it was removed routinely by ultracentrifuging at $105,000 \mathrm{~g}$ for $90 \mathrm{~min}$.

Ethanol dehydrogenase. The enzyme was assayed with ethanol and acetaldehyde as substrates (Fig. $3 a, b$ ). It showed a broader $\mathrm{pH}$ optimum with acetaldehyde than with ethanol (Fig. $3 c$ ), was specific for NAD and precipitated principally in the 40 to $60 \%$ saturation $\left(\mathrm{NH}_{4}\right)_{2} \mathrm{SO}_{4}$ fraction.
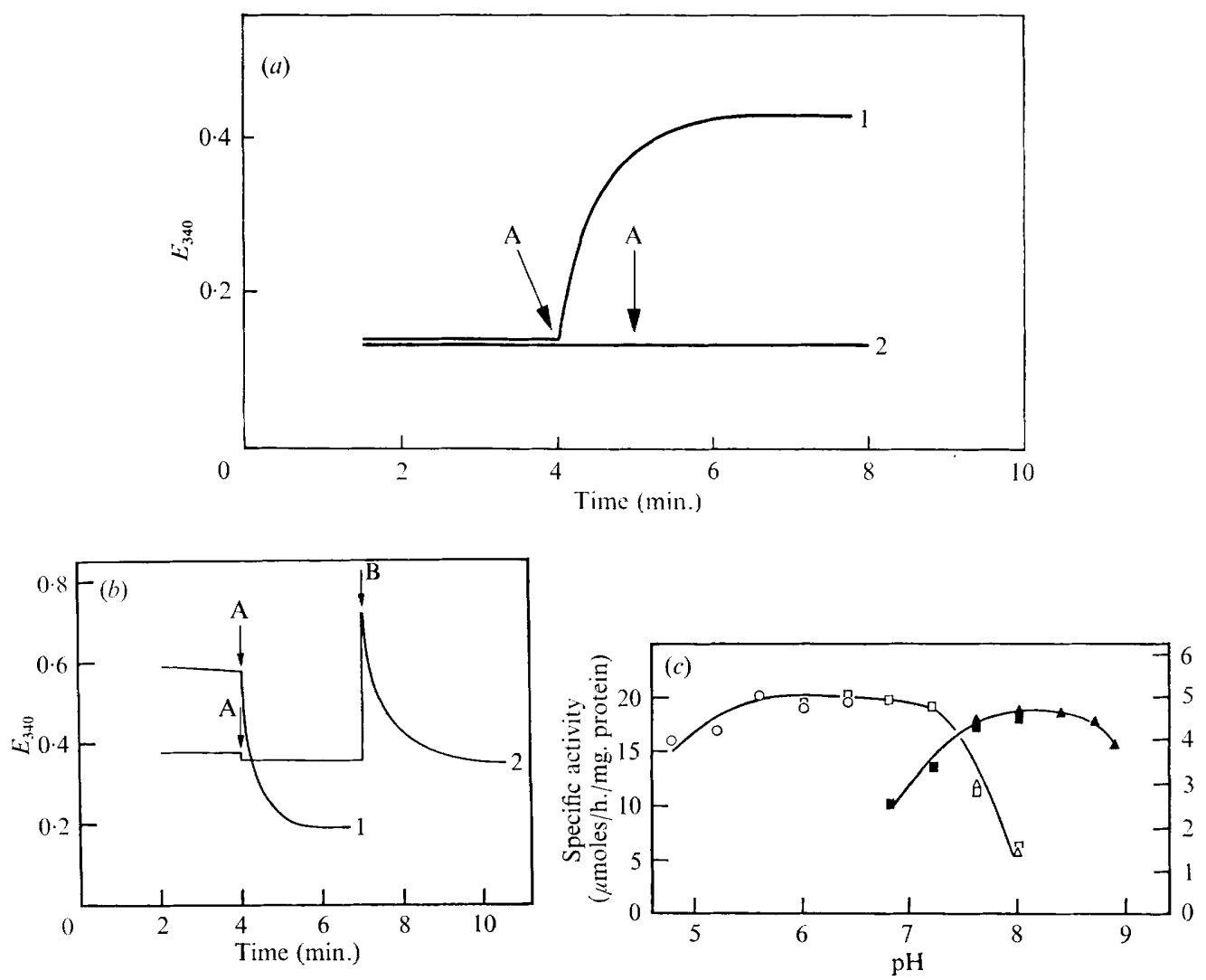

Fig. 3. Reversibility, coenzyme specificity and $\mathrm{pH}$ optimum of ethanol dehydrogenase. (a) Ethanol as substrate. Cuvettes contained $2.4 \mathrm{ml}$. $60 \mathrm{~mm}$-tris buffer, pH $8.5 ; 0.2 \mathrm{ml}$. I mM-NAD or NADP; $0 . \mathrm{I} \mathrm{ml}$. $3 \mathrm{M}$-ethanol; $0.1 \mathrm{ml}$. bacterial extract $(8.3 \mathrm{mg}$. protein/ml. buffer) and water to $3 \mathrm{ml}$. Curve I, NAD; 2, NADP. Arrows indicate addition of ethanol. (b) Acetaldehyde as substrate. Cuvettes contained $2.4 \mathrm{ml}$. $0.6 \mathrm{M}$-K-phosphate buffer, $\mathrm{pH} 7.0 ; 0.2 \mathrm{ml}$. I mM-NADH or $0 . \mathrm{I} \mathrm{ml}$. I mM$\mathrm{NADPH} ; 0 . \mathrm{I} \mathrm{ml} .0 .5 \mathrm{~mm}$-acetaldehyde; $0.1 \mathrm{ml}$. extract $(8.3 \mathrm{mg}$. protein $/ \mathrm{ml}$. buffer $)$ and water to $3 \mathrm{ml}$. Curve I, NADH; 2, NADPH. Acetaldehyde was added at A to initiate reaction and $0.2 \mathrm{ml}$. I mM-NADH was added to 2 at B. (c) Effect of $\mathrm{pH}$ on ethanol dehydrogenase. Conditions as for $(a)$ and $(b)$ except bacterial extract $(6.5 \mathrm{mg}$. protein $/ \mathrm{ml}$. water) and buffers: $0,0.06 \mathrm{M}$-citrate phosphate, $\square$, $0.06 \mathrm{M}-\mathrm{K}$-phosphate; $\triangle, 0.06 \mathrm{M}$-tris. Open symbols, acetaldehyde substrate; solid symbols, ethanol. The right-hand ordinate refers to ethanol substrate. 
NAD-NADP transhydrogenase. The presence of this enzyme could not be detected.

Acetaldehyde dehydrogenase. Experiments with crude extracts, $105,000 \mathrm{~g}$ supernatants and $\left(\mathrm{NH}_{4}\right)_{2} \mathrm{SO}_{4}$ fractions all failed to detect a coenzyme A-dependent acetaldehyde dehydrogenase of the Escherichia coli type (Pinchot \& Racker, I95I ; Dawes \& Foster, I956).

Lactate dehydrogenase. Efforts to demonstrate an NAD-dependent lactate dehydrogenase were frustrated by the presence of the very active pyruvate decarboxylase and ethanol dehydrogenase, and fractions freed of these enzymes did not display activity towards lactate. However, the presence of a rather weak lactate dehydrogenase, with optimum activity at $\mathrm{pH} 7 \cdot 6-8 \cdot 0$, was demonstrated by coupling to ferricyanide and measuring $\Delta E_{405}$ (Fig. $4 a, b$ ).
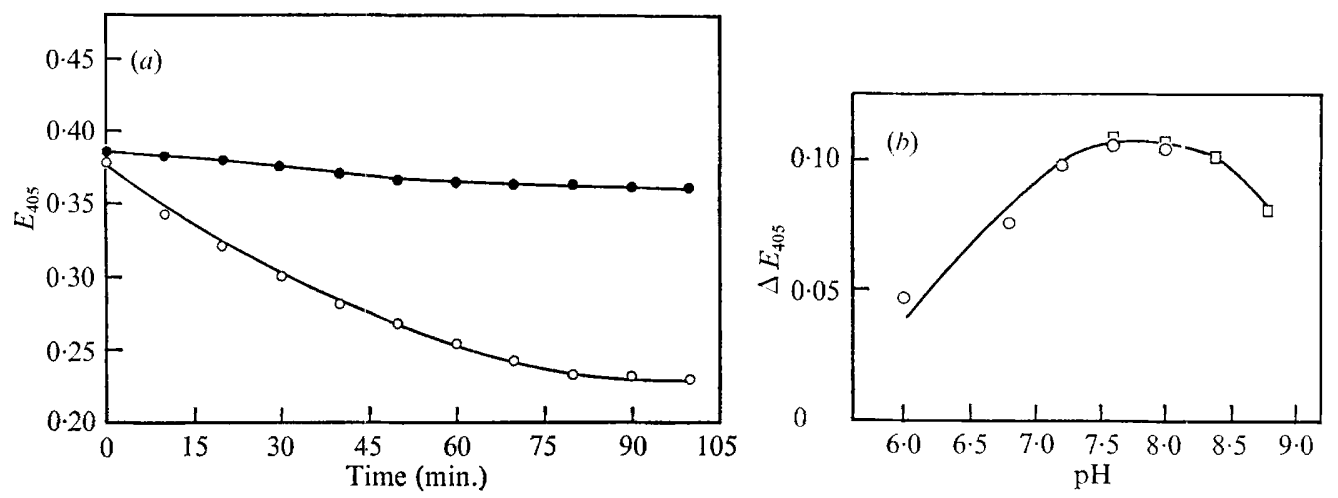

Fig. 4. Lactate dehydrogenase assay. (a) Progress of reaction. Cuvettes contained: I 4 ml. 0.I M-Kphosphate, pH 8.0; 0.I ml. Io mM-potassium ferricyanide; $0.2 \mathrm{ml}$. $0 . \mathrm{I} \mathrm{M}$-lithium lactate; $0.2 \mathrm{ml}$. bacterial extract $(8.6 \mathrm{mg}$. protein $/ \mathrm{ml}$. buffer) $(\bigcirc)$ or water (control) $(O)$ and water to $3 \mathrm{ml}$. After incubation for $15 \mathrm{~min}$. at $22^{\circ}$ the reaction was initiated by addition of the substrate. $(b)$ Effect of $\mathrm{pH}$. Conditions as for $(a)$ except $\mathrm{O} \cdot \mathrm{I} \mathrm{M}-\mathrm{K}$-phosphate $(O)$ and $\mathrm{O} \cdot \mathrm{I} \mathrm{M}$-tris buffer $(\square)$ used and the reaction continued for $50 \mathrm{~min}$.

Table 3. Detection of pyruvate thioclastic enzyme by pyruvate-formate exchange reaction

\begin{tabular}{|c|c|c|c|}
\hline Reaction mixture & $\begin{array}{l}\text { Isolated pyruvate } \\
2,4 \text {-dinitrophenyl- } \\
\text { hydrazone (mM) }\end{array}$ & $\begin{array}{l}\text { Total radioactivity } \\
\text { (counts } / 0 \cdot 2 \mathrm{ml} . / \\
100 \mathrm{~min} .)\end{array}$ & $\begin{array}{c}\text { Specific activity } \\
\text { (counts/min. } / \\
\mu \text { mole) }\end{array}$ \\
\hline$\left[{ }^{14} \mathrm{C}\right]$-Formate & 0 & 270 & $\longrightarrow$ \\
\hline$\left[{ }^{14} \mathrm{C}\right]$-Formate + pyruvate & 0.50 & 459 & I 8 \\
\hline $\begin{array}{l}{\left[{ }^{14} \mathrm{C}\right]-\text { Formate }+ \text { pyruvate }+ \text { boiled }} \\
\text { yeast extract }\end{array}$ & 0.49 & I I 7 I & 90 \\
\hline $\begin{array}{l}{\left[{ }^{14} \mathrm{C}\right]-\text { Formate }+ \text { pyruvate }+ \text { boiled }} \\
\text { Erwinia amylovora extract }\end{array}$ & 0.52 & 1728 & I 45 \\
\hline
\end{tabular}

Pyruvate thioclastic enzyme. The production of formate in pyruvate fermentation suggested the presence of the thioclastic enzyme but no significant activity could be detected in crude extracts unless they were supplemented with boiled extracts of either baker's yeast or Erwinia amylovora (Table 3). Even then the incorporation of $\left[{ }^{14} \mathrm{C}\right]$-formate into pyruvate was very low.

Formate dehydrogenase and formate hydrogenlyase. Neither intact organisms nor extracts produced $\mathrm{H}_{2}$ and $\mathrm{CO}_{2}$ from formate, nor did they reduce methylene blue or benzyl viologen in the presence of this substrate.

$\alpha$-Acetolactate decarboxylase. Extracts decarboxylated $\alpha$-acetolactate rapidly whereas $\mathrm{CO}_{2}$ was evolved but slowly by intact bacteria. This indicated a permeability barrier to the substrate under the conditions used (Fig. 5). 


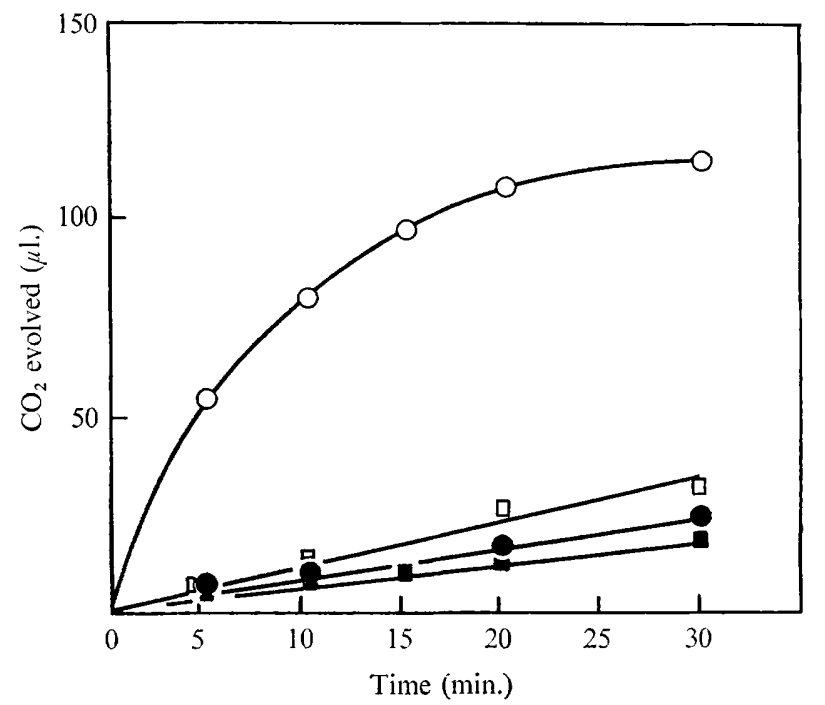

Fig. 5. Decarboxylation of $\alpha$-acetolactate by intact cells and extracts. Warburg flasks contained: I. $5 \mathrm{ml}$. $0 . \mathrm{I} \mathrm{M}$-K-phosphate buffer, $\mathrm{pH} 6.0 ; 1.0 \mathrm{ml} .4 .76 \mathrm{~mm}-\alpha$-acetolactate; $0.5 \mathrm{ml}$. bacterial suspension $\left(20.7 \mathrm{mg}\right.$. dry wt $/ \mathrm{ml}$.) or bacterial extract $\left(9.8 \mathrm{mg}\right.$. protein $/ \mathrm{ml}$.). Temperature, $30^{\circ}$. Atmosphere, $\mathrm{N}_{2}$. The reaction was started by tipping the suspension or extract from the side arm to the main compartment. $\square$, Intact bacteria; $\bigcirc$, bacterial extracts. Solid symbols are controls without substrate.

\section{DISCUSSION}

Considerable controversy has surrounded the classification of the genus Erwinia, which is placed in the Enterobacteriaceae family (Bergey's Manual of Determinative Bacteriology, 1957). It is generally agreed that E. amylovora, the causal organism of fire-blight, differs biochemically and pathogenically from the pectinolytic soft-rot Erwinia species (Martinec \& Kočur, I963; Edwards \& Ewing, 1967) for which a new genus Pectobacterium was suggested by Waldee (1945), a differentiation supported by numerical taxonomy (Lockhart \& Koenig, I965). Martinec \& Kočur (1963) have recommended that the genus Erwinia should include only two species and one variety, namely E. amylovora, E. amylovora var. salicis and $E$. carotovora. They have shown that the relationship between Erwinia and other genera of the Enterobacteriaceae is such that E. amylovora resembles Shigella and E. carotovora resembles Klebsiella and Enterobacter. Recent work on DNA base ratios indicates that Erwinia species have GC values within the span 50 to $56 \%$ (Marmur, Falkow \& Mandel, 1963; Fedorova, I964; Starr \& Mandel, I969) which falls within the accepted range for the Enterobacteriaceae.

The Enterobacteriaceae are characterized by mixed acid fermentations of glucose with two principal variations in the formation of neutral compounds, typical of Escherichia coli and Aerobacter aerogenes respectively; the aerogenes type produces acetoin, diacetyl and butane 2,3-diol in addition to the ethanol produced in the coliform fermentation. It is a feature of these fermentations that the mechanism for alcohol production, via thioclastic fission of pyruvate to acetyl CoA, which is then reduced by a coenzyme A-dependent acetaldehyde dehydrogenase (Dawes \& Foster, I956), predicts a theoretical maximum yield of I mole ethanol/mole glucose fermented (Dawes, I963). In practice, the highest yield recorded for $E$. coli is $0.8 \mathrm{~mole} / \mathrm{mole}$ glucose (Stokes, 1949). Consequently the finding (Sutton \& Starr, 1959) that Erwinia amylovora fermented glucose with the stoichiometry

Glucose $\longrightarrow \mathrm{I} \cdot 55$ ethanol $+0 \cdot \mathrm{I} 8$ lactate $+\mathrm{I} \cdot 6 \mathrm{I} \mathrm{CO}_{2}$ 
indicated a deviation from the Enterobacteriaceae pattern. We have now shown the presence in the organism of a yeast-type pyruvate decarboxylase, which converts pyruvate to acetaldehyde and $\mathrm{CO}_{2}$. This enzyme has not been recorded in any other member of the Enterobacteriaceae family. Indeed it is of very limited occurrence in bacteria and previously only Acetobacter suboxydans (King \& Cheldelin, 1954), Zymomonas mobilis (De Moss, 1953), Z. anaerobia (McGill, Ribbons \& Dawes, 1965) and Sarcina ventriculi (Bauchop \& Dawes, 1959) were known to possess the enzyme. The pyruvate decarboxylase of Erwinia amylovora seems to differ from the other recorded examples in having a very tightly-bound thiamine pyrophosphate prosthetic group. The presence of an NAD-dependent ethanol dehydrogenase permits the reduction of acetaldehyde to ethanol and the two enzymes can thus account for the high yield of ethanol observed in the fermentation of glucose. When pyruvate replaces glucose as the fermentation substrate there is available the equivalent of $4 \mathrm{H}$ less reducing power, thus accounting for the low yield of ethanol and the accumulation of free acetaldehyde observed in this work.

A coliform-type of thioclastic reaction converting pyruvate to acetyl CoA and formate was inferred from the incidence of formate in the fermentation products, although the yield was low. Evidence for the presence of the enzyme has been obtained but $\left[{ }^{14} \mathrm{C}\right]$-formate incorporation was weak. While negative results can never be conclusive, our inability to detect a coenzyme A-dependent acetaldehyde dehydrogenase, coupled with the low activity of the thioclastic reaction, suggests that the coliform route of ethanol formation is not significant in Erwinia amylovora. The fact that the yield of acetate was considerably in excess of that of formate indicates the existence of other reactions leading to acetate, e.g. coupled oxidoreduction of pyruvate to lactate, acetate and $\mathrm{CO}_{2}$ (Fig. 6).

The presence of pyruvate decarboxylase is of interest in relation to acetoin formation. Two mechanisms are known in micro-organisms (Juni, I952), one characteristic of organisms possessing pyruvate decarboxylase and the other, in those that do not have the enzyme, involving $\alpha$-acetolactate as an intermediate, together with $\alpha$-acetolactate decarboxylase. Erwinia amylovora thus appears to be the first bacterium recorded with both pyruvate decarboxylase and $\alpha$-acetolactate decarboxylase enzymes. While we have not been concerned with evaluating their relative significance in acetoin formation, it may be noted by comparing the results in Table $\mathrm{I}$ that a large increase in acetoin yield resulted in a much smaller decrease in acetaldehyde yield, indicating that diversion of acetaldehyde cannot account for much of the additional acetoin formed. Since a survey of E. amylovora by Martinec \& Kočur (I964) revealed that $\mathrm{I} 2$ of the 49 strains studied did not produce acetoin, it would be instructive to

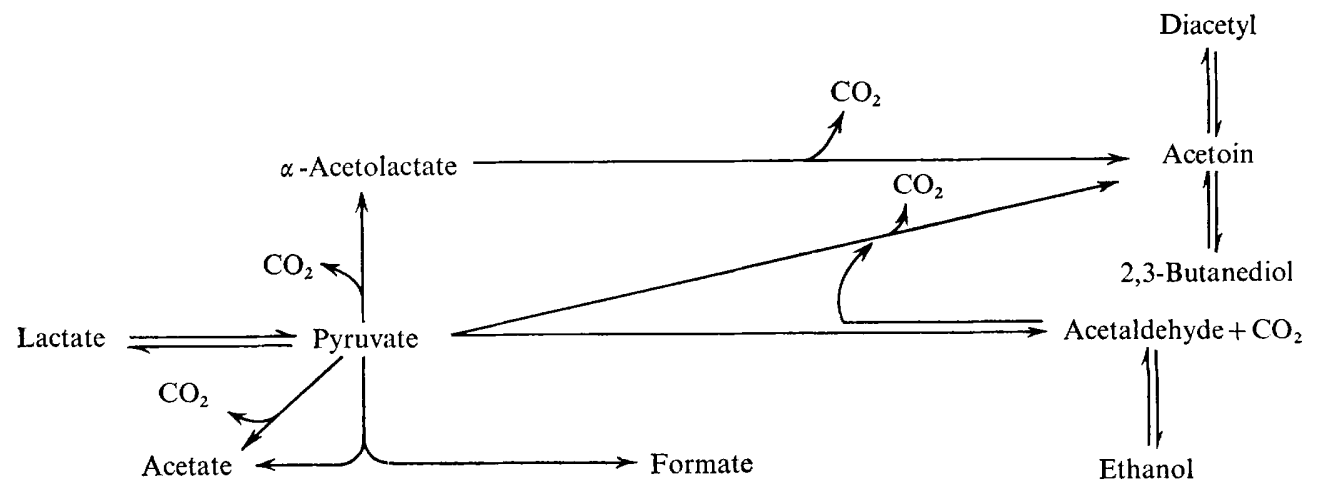

Fig. 6. Fermentation of pyruvate of Erwinia amylovora. 
know whether these organisms lacked both pyruvate decarboxylase and $\alpha$-acetolactate decarboxylase.

Martinec \& Kočur (1964) reported that sodium formate was utilized by all 49 strains of Erwinia amylovora examined in their taxonomic study of this species. Utilization was judged on the basis of the increase in $\mathrm{pH}$ in a modified Koser's medium (containing formate) with phenol red as indicator (Dr M. Kočur, personal communication). All our attempts to detect the metabolism of formate by intact organisms and extracts of E. amylovora have failed and we attribute the positive diagnostic bacteriological test to an artifact of the method.

While the effect of $\mathrm{pH}$ was incidental to our investigation it is well known that the products of coli-aerogenes fermentations are influenced considerably by this parameter. At low $\mathrm{pH}$ the yield of lactate increases at the expense of acetate, formate, $\mathrm{H}_{2}$ and $\mathrm{CO}_{2}$, as does acetoin and related compounds.

Thus Erwinia amylovora differs from all other Enterobacteriaceae in possessing a pyruvate decarboxylase, which explains the atypical fermentation balance recorded by Sutton \& Starr (1959) with high ethanol yield. It would be interesting to know the distribution of pyruvate decarboxylase in other members of the genus Erwinia, particularly in relation to the pectinolytic organisms.

The assistance of Miss C. M. Ward with some of the experiments is gratefully acknowledged.

\section{REFERENCES}

Allen, C. F. H. (1930). The identification of carbonyl compounds by use of 2,4-dinitrophenylhydrazine. Journal of the American Chemical Society 52, 2955-2959.

ArK, P. A. (1937). Variability in the fire-blight organism, Erwinia amylovora. Phytopathology 27, I-28.

BAUCHOP, T. \& DAWES, E. A. (1959). Metabolism of pyruvic and formic acids by Zymosarcina ventriculi. Biochimica et biophysica acta 36, 294-6.

BAUChOP, T. \& Dawes, E. A. (1968). The metabolism of formic acid by Sarcina ventriculi. Journal of General Microbiology 52, 195-203.

Bergey's Manual of Determinative Bacteriology (1957). 7th edn. Baltimore: Williams \& Wilkins.

BONNICHSEN, R. (I963). Ethanol. Determination with alcohol dehydrogenase and DPN. In Methods of Enzymatic Analysis, pp. 285-289. Edited by H. U. Bergmeyer. New York and London: Academic Press.

DAwES, E. A. (1963). Comparative aspects of alcohol formation. Journal of General Microbiology 32, I 5 I-I 56.

DAwes, E. A. \& Foster, S. M. (1956). The formation of ethanol in Escherichia coli. Biochimica et biophysica acta 22, 253-265.

DE LEY, J. (1962). Comparative biochemistry and enzymology in bacterial classification. In Microbial Classification, pp. I64-195. Edited by G. C. Ainsworth and P. H. A. Sneath. Cambridge University Press.

DE Moss, R. D. (1953). Routes of ethanol formation in bacteria. Journal of Cellular and Comparative Physiology 4I, Suppl. I, 207-224.

EDWARDS, P. R. \& EwING, W. H. (1967). Identification of Enterobacteriaceae, 2nd edn. Minneapolis: Burgess Publishing Co.

Fedorova, L. S. (1964). The nucleotide composition of deoxyribonucleic and ribonucleic acids of the incitant of toxic bacteriosis of water melons. (In Russian.) Mikrobiologyia 33, 968.

Friedemann, T. E. \& Haugen, G. E. (I943). Pyruvic acid. II. The determination of keto acids in blood and urine. Journal of Biological Chemistry 147, 4I 5-442.

GомокI, G. (1955). Preparation of buffers for use in enzyme studies. In Methods in Enzymology, vol. I, pp. 138-146. Edited by S. P. Colowick and N. O. Kaplan. New York and London: Academic Press.

Holzer, E., Söling, H.-D., Goedde, H. W. \& Holzer, H. (I963). Thiamine pyrophosphate. In Methods of Enzymatic Analysis, pp. 602-605. Edited by H. U. Bergmeyer. New York and London: Academic Press.

Hughes, D. E. (195I). A press for disrupting bacteria and other micro-organisms. British Journal of Experimental Pathology 32, 97.

Hullin, R. P. \& NoBle, R. L. (I953). Determination of lactic acid in microgram quantities. Biochemical Journal 55, 289-29I. 
Johnson, G. R. A. \& Scholes, G. (1954). Micro-determination of acetaldehyde as its 2,4-dinitrophenylhydrazone. The Analyst 79, 2 1 7-219.

JUNI, E. (1952). Mechanisms of formation of acetoin by bacteria. Journal of Biological Chemistry 195, 71 5726.

KatZNELSON, H. (1958). Metabolism of phytopathogenic bacteria. II. Metabolism of carbohydrates by cell-free extracts. Journal of Bacteriology 75, 540-543.

KING, T. E. \& Cheldelin, V. H. (1954). Pyruvic carboxylase of Acetobacter suboxydans. Journal of Biological Chemistry, 208, 82 I-83I.

Kramer, P. J. G. \& VAN DuIN, H. (I954). The separation and identification of normal aliphatic aldehydes and methyl ketones. Recueil des travaux chimiques des Pays-Bas 73, 63-67.

Krampitz, L. O. (1948). Synthesis of $\alpha$-acetyl lactic acid. Archives of Biochemistry 17, 8 I-85.

Lamanna, C. \& Mallette, M. F. (I954). Use of glass beads for the mechanical rupture of micro-organisms in concentrated suspensions. Journal of Bacteriology 67, 503-504.

LOCKHART, W. R. \& KOENIG, K. (1965). Use of secondary data on numerical taxonomy of the genus Erwinia. Journal of Bacteriology 90, I638-1644.

MCGill, D. J., Ribbons, D. W. \& Dawes, E. A. (I965). Carbohydrate metabolism and growth yield coefficients of Zymomonas anaerobia. Biochemical Journal 97, 44-45P.

Marmur, J., Falkow, S. \& Mandel, M. (I963). New approaches to bacterial taxonomy. Annual Review of Microbiology $17,329-372$.

Martinec, T. \& Kočur, M. (1963). Taxonomická studie rodu Erwinia. Folia Facultatis Scientiarum Naturalium Universitatis Purkynianae Brunensis, Biologia 2 4, I.

MARTINEC, T. \& KočUr, M. (I964). A taxonomic study of Erwinia amylovora (Burrill, I 882) Winslow et al. 1920. International Bulletin of Bacteriological Nomenclature and Taxonomy $\mathbf{1 4}, 5$.

Morey, A. V. \& Juni, E. (I968). Studies on the nature of the binding of thiamine pyrophosphate to enzymes. Journal of Biological Chemistry 243, 3009-3019.

NeIsH, A. C. (1952). Analytical Methods for Bacterial Fermentation. Saskatoon: National Research Council of Canada, Report no. 46-8-3.

Ross, J. H. (1953). Infrared spectra for analysis of aldehyde and ketone 2,4-dinitrophenylhydrazones. Analytical Chemistry 25, I 288-I303.

STARR, M. P. (1949). The nutrition of phytopathogenic bacteria. I. Minimal nutritive requirements of the genus Xanthomonas. Journal of Bacteriology 5I, I3I-I42.

StarR, M. P. \& MANDEL, M. (1969). DNA-base composition and taxonomy of phytopathogenic and other enterobacteria. Journal of General Microbiology 56, I $13-123$.

Stickland, L. H. (I95I). The determination of small quantities of bacteria by means of the biuret reaction. Journal of General Microbiology 5, 698-703.

StoKes, J. L. (1949). Fermentation of glucose by suspensions of Escherichia coli. Journal of Bacteriology $\mathbf{5 7}$, I47-I58.

STRaIN, H. H. (1935). 3-Nitrobenzohydrazones, 2,4-dinitrophenylhydrazones and the separation of hydrazones by adsorption. Journal of the American Chemical Society 57, 758-76I.

Strecker, H. J., WoOd, H. G. \& Krampitz, L. O. (I950). Fixation of formic acid in pyruvate by a reaction not utilizing acetyl phosphate. Journal of Biological Chemistry r82, 525-540.

Sutton, D. D. \& STARr, M. P. (I959). Anaerobic dissimilation of glucose by Erwinia amylovora. Journal of Bacteriology 78, 427-43I.

Sutton, D. D. \& STARR, M. P. (I960). Intermediary metabolism of carbohydrate by Erwinia amylovora. Journal of Bacteriology 8o, 104-I IO.

Timmons, C. J. (I957). Spectroscopic studies. Part I. 2,4-Dinitrophenylhydrazones in neutral and in alkaline solutions. Journal of the Chemical Society, 2613-2623.

Umbreit, W. W., Burris, R. H. \& Stauffer, J. F. (1964). Manometric Techniques, 4th edn. Minneapolis: Burgess Publishing Co.

WALDEE, E. L. (1945). Comparative studies of some peritrichous phytopathogenic bacteria. Iowa State Journal of Science r9, 435-484.

Wieland, O. (I963). L(+) Lactate. Determination with lactic dehydrogenase from yeast. In Methods of Enzymatic Analysis, pp. 271-275. Edited by H. U. Bergmeyer. New York and London: Academic Press. 